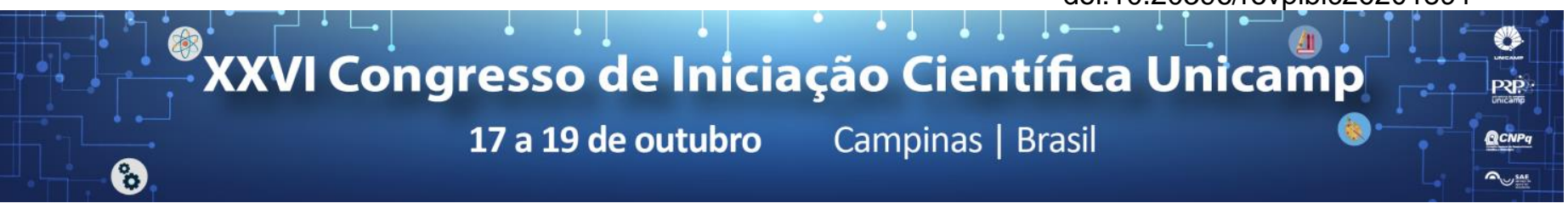

\title{
Análise da degradação, vida útil e qualidade de imagem da placa fósforo fotoestimulável.
}

\section{Amanda Achkar Coli*; Gustavo Nascimento de Souza Pinto; Francisco Haiter Neto}

\section{Resumo}

Com os avanços em relação aos exames de imagem, a radiografia digital surgiu como uma ferramenta de escolha para o diagnóstico. Frequentemente a placa de fósforo fotoestimulável (PSPs) tem sido utilizadas na prática odontológica. Entretanto a longevidade das PSPs ainda não foi bem estabelecida. O objetivo desse estudo foi determinar a vida útil e a quantidade de degradação da PSPs. Uma PSP nova foi exposta aos raios $\mathrm{X}$ e processada no sistema Express (Instrumentarium Dental Inc. Milwaukee, WI - U.S.A). Foi mensurada a média dos tons de cinza de cada degrau e de uma área controle fora dos degraus. Os dados foram analisados usando o teste t-Student, com um nível de significância de $99 \%$. Os resultados desse estudo revelam uma deterioração das PSPs em relação a quantidade de exposição.

Palavras-chave:

Placa de fósforo fotoestimulável, degradação, vida útil.

\section{Introdução}

O diagnóstico está intimamente ligado à qualidade de imagem, uma vez que radiografias com qualidade reduzida podem ocultar informações importantes. Diante disso, o estado físico e a boa conservação da placa de fósforo fotoestimulável (PSP) interfere diretamente nessa qualidade.

O objetivo do estudo foi avaliar a degradação da PSP após repetidas exposições à radiação e processamento.

\section{Resultados e Discussão}

Foi utilizada uma PSP nova, um dispositivo de acrílico fixo visando a padronização das imagens e uma escala de alumínio. Com um tempo de exposição de 0,08 segundos, $70 \mathrm{kV}, 7 \mathrm{~mA}$ e a distância de 40 centímetros entre o ponto focal e o receptor.

Foram realizados 60 imagens por dia durante 5 dias na semana, a média dos tons de cinza foi calculada a partir de um ROI de 0,10X0,10 cm, utilizando uma escala de alumínio de 12 degraus. Todas as imagens foram processadas no mesmo aparelho (Express) e analisadas no software Image J (Instituto Nacional de Saúde, EUA). Foram realizadas 800 imagens ao total, durante 14 dias, com uma média de 61 imagens/dia. Após a análise das imagens nota-se diferença entre os valores obtidos em cada um dos degraus da escala de alumínio e também fora dela, apresentando uma queda na média dos tons de cinza. Houve constante degradação, principalmente a patir da $400^{\circ}$ aquisição.

Gráfico 1. Demosntração das regiões da placa, desde a primeira análise até a última análise.

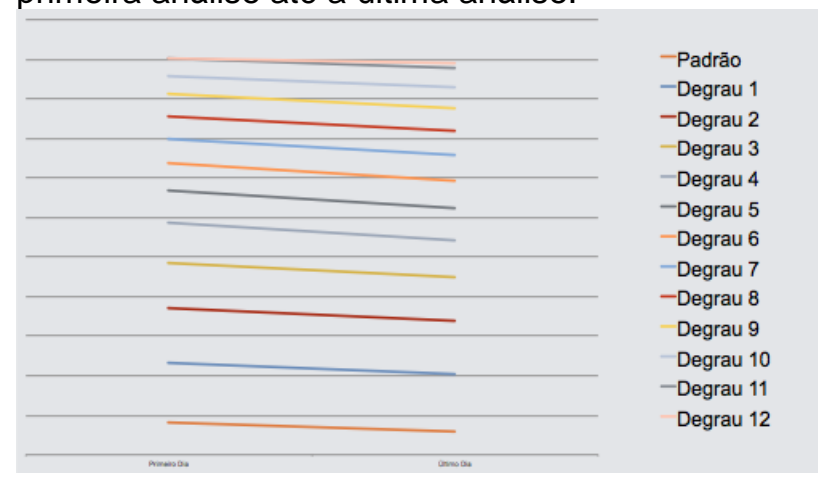

Tabela 1. Valores médios dos pixels iniciais, finais e o erro padrão para cada analise da placa de fósforo.

\begin{tabular}{|c|c|c|c|}
\hline & Inicial & Final & $\begin{array}{c}\text { Erro } \\
\text { padrão }\end{array}$ \\
\hline Padrão & 1.041 .329 & 976.057 & 19,9407 \\
\hline Degrau 1 & 1.502 .807 & 1.410 .622 & 0,0022 \\
\hline Degrau 2 & 1.913 .217 & 1.816 .347 & 0,0023 \\
\hline Degrau 3 & 2.256 .990 & 2.147 .693 & 0,0023 \\
\hline Degrau 4 & 2.558 .599 & 2.427 .259 & 0,0022 \\
\hline Degrau 5 & 2.801 .069 & 2.666 .322 & 0,0021 \\
\hline Degrau 6 & 3.016 .938 & 2.875 .961 & 0,0019 \\
\hline Degrau 7 & 3.201 .552 & 3.072 .765 & 0,0017 \\
\hline Degrau 8 & 3.372 .529 & 3.253 .551 & 0,0015 \\
\hline Degrau 9 & 3.536 .202 & 3.429 .041 & 0,0012 \\
\hline Degrau 10 & 3.679 .391 & 3.589 .172 & 0,0009 \\
\hline Degrau 11 & 3.804 .133 & 3.733 .165 & 0,0006 \\
\hline Degrau 12 & 3.850 .949 & 3.771 .635 & 0,0007 \\
\hline
\end{tabular}

\section{Conclusões}

O estudo revelou a ocorrência de degradação da placa de fósforo fotoestimulável (PSP) devido a repetida utilização. Demonstrado pela queda objetiva de aproximadamente $9 \%$ dos valores finais em relação aos iniciais.

\section{Agradecimentos}

Ao programa CNPq/PIBIC pelo financiamento do projeto de pesquisa, à FOP pela concessão da bolsa de Iniciação Científica e aos membros do departamento de Radiologia pelo apoio durante a execução do trabalho.

Wenzel A, Møystad A. Work ow with digital intraoral radiography: A systematic review. Acta Odontol Scand 2010;68:106-14.

Udupa H, Mah P, Dove SP, McDavid WD. Oral Surg Oral Med Oral Pathol Oral Radiol 2013;116:774-83 